\title{
Towards a new decade in Greenland geology Review of the Survey's activities in 1989
}

\author{
Martin Ghisler
}

\author{
Director
}

Nineteen-eighty-nine brings to an end a decade which has seen many changes in the demands and aspirations expressed by society concerning geological investigations in Greenland. The Geological Survey of Greenland (GGU) has responded to these new expectations by seeking to change the emphasis of its geological activities. Since its inception more than 40 years ago, GGU has surveyed the framework of Greenland geology through a series of mapping programmes and regional investigations aimed at establishing a solid scientific foundation upon which applied and economic geological and hydrological activities could be based. In later years, applied and economic activities have played an increasing role in GGU's planning, and 1989 has seen a continuation of this trend as GGU meets the challenge of a new decade.

During late 1988 and 1989 a detailed internal evaluation of GGU's activities was made, based on the prevailing budgetary situation and the new developments in working obligations experienced during recent years. At the end of the year, the staff of 102 scientists and technical and administrative personnel was reorganised into six main units (Geological Mapping, Geochemistry, Mineral Resources, Petroleum Geology, Glaciology and Glacial Geology, Administration). Personnel were transferred from Geological Mapping to Mineral Resources and Petroleum Geology in order to support the increasing activity in applied geology.

A number of new initiatives have been taken to facilitate the availability of relevant geological, geophysical and geochemical data to the mining industry:

- establishment of geological databases,

- development and production of digitalised maps,

- establishment of a central drill core storage facility in Copenhagen from earlier mining and exploration activities.

The distribution and exchange of GGU publications were re-evaluated. The Bulletin and Report Series continue with new designs, and the editor's work is now supported by an editorial board. Presentation of preliminary field data and analytical results is speeded up by a new series, the Open File Series, which will present new information in an essentially unedited form. The content of the annual Report of Activities is rearranged in order to give the scientific world, industry and society in general a broad idea of the scope of GGU's activities.

Field projects during 1989 were carried out as planned, with a total of 70 participants. One group in North-East Greenland worked out from a base camp near Danmarkshavn. Its main task is reconnaissance geological mapping and preliminary evaluation of the mineral potential. Another group undertook detailed investigations in the Disko Bugt area of West Greenland, with special emphasis on studies related to the formation of mineral deposits and the evaluation of the offshore hydrocarbon potential. The collection of glacio-hydrological data related to hydropower developments in West Greenland also continued.

Sulphide and scheelite mineralisation was studied by two groups near Maarmorilik and in inner Godthåbsfjord. Special sedimentological investigations in Jameson Land, East Greenland, were continued. One group supported by the Carlsberg Foundation, Copenhagen, undertook collection of exceptionally well-preserved fossils from a locality at J. P. Koch Fjord in North Greenland.

GGU assisted the Mineral Resources Administration during 1989 with geological and geophysical inspection and consultation in relation to exploration activities of concessionaires at Maarmorilik, Jakobshavn, Søndre Strømfjord, Ivituut and Narsaq in western Greenland, and at Kangerdlugssuaq and Jameson Land on the east coast. The discovery of stratabound gold in the Skaergaard intrusion, East Greenland, recently reported in the international press has to some extent increased the attention of the mining industry to Greenland as an exploration target.

During the year the 1:500 000 geological map sheet 'Nyeboe Land' from North Greenland and the 1:100 000 map 'Fiskefjord' from the area north of Nuuk/Godthåb were printed. Five reports, two bulletins and one map sheet description were published, along with seven contributions to the Open File Series. As a result of GGU activities some thirty papers were published in international scientific journals in 1989; these are listed together with GGU's own publications on page 57 . 